\title{
CUSTOMER SERVICE AND ITS IMPACT ON CONSUMER BUYING PATTERNS
}

\begin{abstract}
The study focuses on the relationship between customer service and consumer shopping patterns at a selected retailer in Whittlesea, South Africa. The study's primary objectives were to identify the fundamental components of customer service and assess if customers are satisfied with the service levels they obtain from the chosen retailer, and if not, to suggest ways to improve it. Self-administered questionnaires were used to collect data, which was then quantitatively analyzed. As a result, data from 135 respondents were collected using the most efficient and less time-consuming non-probability and convenience sampling method. The findings reveal that customers are dissatisfied with the service levels of the retailer and thus recommend that there should be improvements with: i) Assisting of customers whilst shopping; ii) handling of customer complaints; understanding of customer needs; and iv) general politeness towards customers
\end{abstract}

Keywords: Customer service, purchasing pattern, retailing, customer buying patterns, service quality.

\section{INTRODUCTION}

Customer service is a major activity that a firm needs to master. Thus, customer service strategies need to be executed to retain customers and increase sales. Despite retailers offering low prices for their products, without efficient customer service, it will be hard for them to push sales and reach their sales target. Customer service leads to the satisfaction or dissatisfaction of customers depending on whether it is poor, good, or excellent.

Most successful companies have since recognized the significance of providing outstanding customer service. Courteous and empathetic interaction with a trained customer service representative can mean losing or retaining a customer (Drury, 2020). When a customer enters a firm, they have conjectured that their expectations will be met. These expectations determine their involvement in a purchase situation. Today, if a firm is delivering sincere value to its customers, it is guaranteeing its success rather than sealing its fate in a coffin of corporate greed and advancement at all costs (Adams, 2016). Patrons require assistance, before, during, and after making a sale. Customer service provides this

${ }^{1}$ Tshepo Tlapana, PhD, Department of Corporate Communications and Marketing, Faculty of Business Science, Walter Sisulu University (corresponding author); e-mail: ttlapana@wsu.ac.za. ORCID: 0000-0002-1777-6177.

2 Kwanele Mduba, Department of Corporate Communications and Marketing, Faculty of Business Science, Walter Sisulu University; e-mail: kwanelemduba@gmail.com. BTech: Marketing, Research Assistant, ORCID: 0000-0002-9503-5980. 
support through information, assistance, and creating a trusting environment (Oberlo, 2015).

The main objective of this research is to discover whether consumer buying patterns are influenced by customer service at selected retailer in Whittlesea, South Africa, and to further uncover the fundamental components of customer service.

\section{LITERATURE REVIEW}

\section{Role and importance of customer service}

Cant \& Van Heerden (2017) define customer service as all the activities that an organization puts in place to ensure that value is added to its products and services, as a way to improve the customer experience the moment the customer comes into contact with the organization. Tlapana (2020) further supports that customer service in the retail context refers to the mixture of activities provided by retailers that offer customer support to enhance retail profitability. It is also argued by Jeske, Chimusoro \& Karodia (2015) that customer service is anything a business does for customers that enhances the customer experience. From the perspective of clients, customer service can be defined as the entirety of what a company does to add value to its goods and services.

The customer service process is defined as structured sets of work activity that leads to specified business outcomes for customers (Setia, Venkatesh \& Joglekar, 2013) which can be categorized into three tiers. The first tier is reliability, which means performing the basics well. The second tier is resilience or the ability to respond to failures of the customer service systems. The third tier is referred to as creativity or innovation. Creativity means developing value-added programmes for the customers such as direct store delivery or packaging innovations (Theodoras, Laios, Moschuris, 2005). Elements of customer service comprise all the external factors that stimulate the consumer's mind. The interpretation of the individual elements of Customer service is considered a cognitive activity that involves interpretation within established schemata in memory that are based on existing knowledge structures (Marx, Erasmus, 2006). Customer service can be measured in many dimensions such as service empathy, access time, courtesy of staff, and service quality.

Generally, customer service contributes to the long-term survival, growth, and success of the organization. Furthermore, Lamb, et al. (2015) argues that meeting and exceeding customer expectations lead to profitability. Venetis \& Ghauri (2004) conclude that customer service has been argued to increase the willingness of consumers to purchase again, buy more, buy other services, become less price-sensitive, and inform others about their positive experiences. Figure 1 below depicts how service quality, employee satisfaction, retention, and productivity, lead to customer satisfaction and profitability.

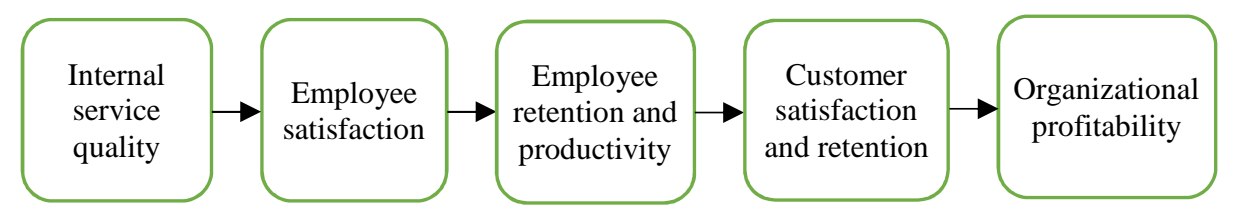

Figure 1. Service-profit chain

Adapted from Cant and Van Heerden (2017). 
The above diagram illustrates the correlation between variables that influence a firm's profitability. These variables include internal service quality, employee satisfaction, employee retention and productivity, customer satisfaction and retention, and organizational profitability.

- Internal service quality - is the quality of the services frontline employees are receiving from the rest of the organization

- Employee satisfaction - if employees are satisfied with their jobs, external customer satisfaction will be easy to achieve

- Employee retention and productivity - Ecstatic and satisfied employees will remain in the firm for longer, translucently their productivity will improve.

- Customer satisfaction and retention - if consumers' needs are met, they will become loyal.

- Organizational profitability - Customer satisfaction leads to customer retention which results to repeat purchases.

\section{Components of customer service}

Customer service components need to be incorporated and executed in such a manner that they retain customers and generate profit. Customer service enhances the consumer experience.

Basic components of customer service are:

\section{Building a long-term relationship with customers}

It is done by communicating with customers, exchanging information, or ideas keeping in mind that in marketing, the customer is 'King'. Ensuring that customers are well informed before making a purchase increases the chances they will be elated (Quickstone Capital, 2016). A firm should measure its customer service or satisfaction frequently by providing customers a podium where they can suggest ways that a firm can use to meet their needs. Companies can give customers questionnaires to rate their service and revisit the areas that require improvement.

\section{Staff visibility}

Staff should be visible on the shop floor so that customers can be assisted. It makes it easier for customers to come and ask for assistance. For example, Pre-suppose that a customer is looking for a shield on the shop floor and they are finding it difficult to find the section of shields (roll-on), staff should be there to attend to them so that the customer does not get exasperated and decide to leave the shop.

\section{Courtesy of staff}

When customers visit a firm or call on the phone, the level of courtesy employees show affects whether a customer buys and whether they come back (Kokemuller, 2020). The hired hands ought to be courteous towards customers. Staff should smile and greet a customer with a friendly smile, by doing that a customer will feel welcome to ask for assistance and they will repeat visiting the firm. Employees are so much more than paid workers, they are ambassadors of a firm's brand and anything that a firm stands for (Timesheets, 2017). 


\section{BENEFITS OF CUSTOMER SERVICE}

Providing good customer service has the following benefits:

\section{Increased customers population}

Repeat sales are not serendipitous, and without creating a positive consumer experience, buyers will go elsewhere (Joseph, 2019). When customers know that their needs are paramount to your company's staff, returning to your establishment is an easy decision. Patrons will become loyal and repeat visiting the firm. Satisfied customers tend to recommend a firm to others. Consequently, that will bring more patrons to a firm (MerchantPro Express, 2016).

\section{Profitability}

With more customers buying at a certain firm, optimistically the firm will become lucrative. Loyal customers tend to be less price-sensitive. Consequently, cash flow will also be increased. When a firm delivers a good service, word of mouth and references are good, it will acquire new customers at a fraction of the cost (Bhasin, 2018).

\section{Better work environment}

The benefits of good customer care can impact the kind of work environment a firm creates (Joseph, 2019). A firm that is constant in providing good customer experiences will yield satisfied customers as a consequence of unsatisfied customers are not easy to deal with.

\section{CUSTOMER SATISFACTION}

In the retail industry, it is all about meeting customers' needs. Customer satisfaction is a result of good or excellent service. Customer satisfaction is a metric used to quantify the degree to which a customer is elated with a product, service, or experience. According to Lamb, et al. (2015), customer satisfaction is a customer response to a product or service in terms of the extent to which consumption meets the customer's anticipations. Ostensibly, meeting customers' anticipations should be one of the main objectives of a firm.

\section{Benefits of customer satisfaction}

Customer satisfaction has the following benefits:

\section{- Greater customer loyalty}

Satisfied patrons eventually become loyal, translucently they will buy more. Loyal customers will recommend the firm to their families and friends.

\section{- Support during a corporate crisis}

Satisfied or loyal patrons want the firm to survive during a corporate crisis, thus they will support it till the end (Megha, 2020).

- Growth in sales revenue

Satisfied or loyal customers will buy more, and they will recommend the firm to others, thus the company will become lucrative. Happy customers always lead to higher profits (Kate, 2015). Brands focussing on customer satisfaction actively will experience healthy sales revenue. 
- Stand out from the competition

Customer satisfaction is the key to making or breaking brands. Exceeding or meeting customers' anticipations distinguishes a firm from its competitors. Satisfied customers will always go and spend where their needs or desires are met (Megha, 2020).

\section{- Increase brand popularity}

Satisfied customers tend to share a firm's content on social media channels. Many people are using social media channels such as Facebook, WhatsApp, Twitter, Instagram, etc, consequently, that will create widespread brand exposure.

\section{CONSUMER BEHAVIOUR}

For a firm to master customer service, it requires a thorough understanding of consumer behaviour. Consumer behaviour describes how consumers make purchase decisions and how they use and dispose of the purchased goods or services (Lamb et al., 2015). Consumer buying decisions are determined by several factors as outlined in figure 2 below.

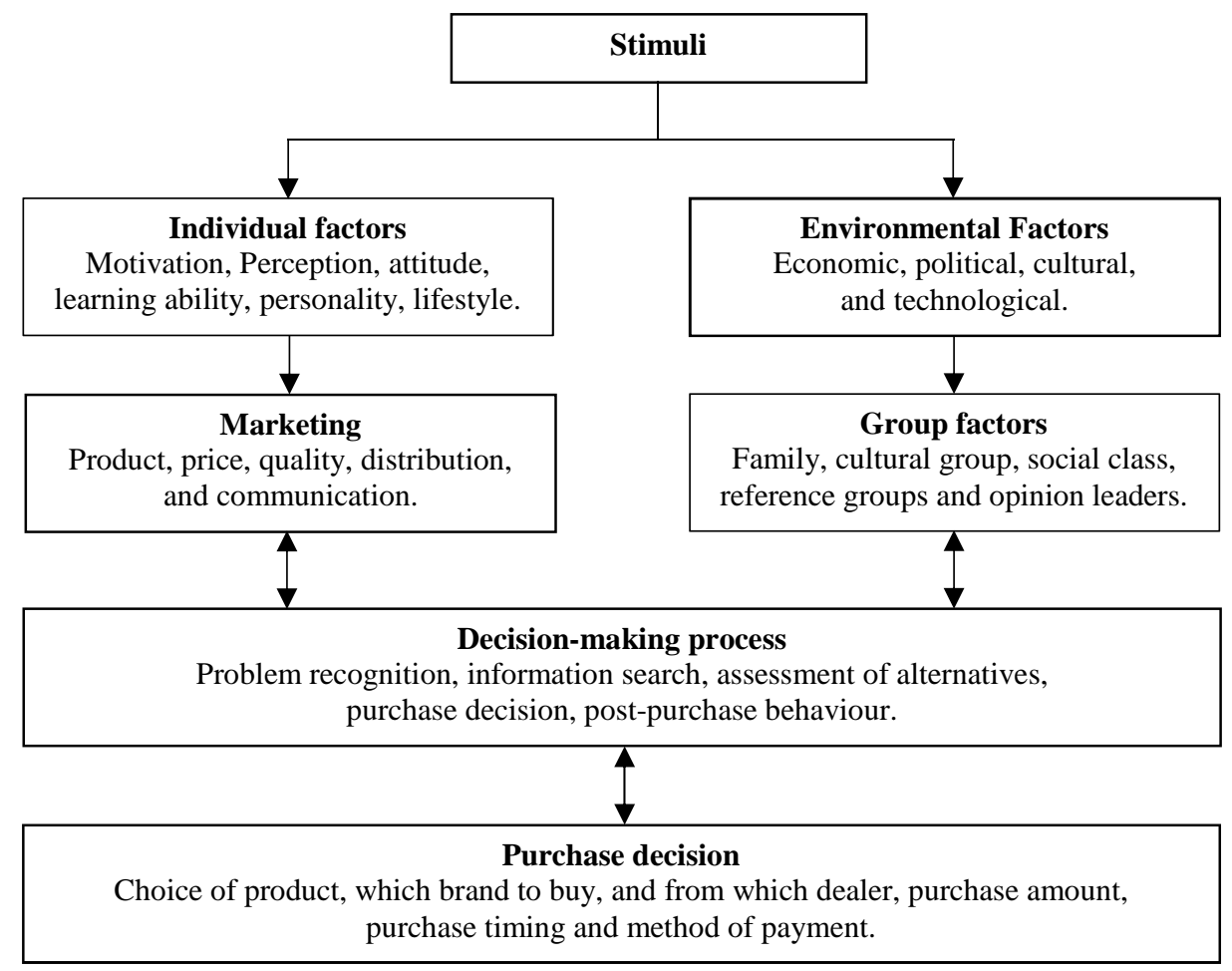

Figure 2. A model of consumer behaviour

Adapted from Cant \& Van Heerden (2017). 
The above diagram illustrates that consumer behaviour is influenced by several factors. These factors include marketing, environmental factors, individual factors, and group factors.

- Marketing factors include the product, price, quality, distribution, and communication. This involves a firm selling good quality products at a reasonable price and communicating effectively with its customers. For example, Shoprite emphasizes that they sell good quality products at lower prices. Shoprite position itself as a retailer that sells at lower prices "Lower prices you can trust, always" is their slogan. Price has an impact on a consumer buying decision.

- Environmental factors include economic, political, cultural, and technological. These factors are in the macro-environment and the business has no control nor influence over these factors. Shoprite's supervisor claims that their marketing team performs environmental scanning monthly to be aware of unfavourable trends.

- Individual factors include motivation, perception, attitude, learning ability, personality, and lifestyle. The store's supervisor claims that they are acutely conscious that patrons do not just buy for the sake of buying, their decisions are influenced by certain individual factors.

- Group factors. Shoprite is acutely aware that the buying decisions of consumers can be influenced by group factors of family, cultural group, social class, reference groups, and opinion leaders.

\section{METHODOLOGY}

The study was both explanatory and quantitative in nature. Explanatory research was conducted to have more insights into the research topic and to identify the extent and nature of cause-and-effect relationships. The target population comprised retail customers from the South African town of Whittlesea. A survey was utilized as a data collection method for primary data from respondents. A structured self-administered questionnaire consisting of closed questions was utilized to gather data from a conveniently selected sample of 135 respondents ranging in age from 18 to 60 years. Questionnaire content covered the perceptions of retail customer service employing a five-point Likert scale (Strongly disagree to strongly agree). Data obtained from the questionnaires were meticulously checked to ensure that it is flawless. Data was scrutinized to ensure the precision and reliability of the results.

\section{Results}

The figure above shows that the preponderance of shoppers were females (58\%), followed by males $(42 \%)$. It was uncovered that males had a negative attitude towards the activity of shopping. They have a conjecture that shopping is for females.

Figure 4 illustrates that the preponderance of respondents $(33.33 \%)$ are middle-aged (30-40), followed by young consumers (18-29) with a response rate of $30 \%$, the age group that is between 41 and 55 were $25 \%$, lastly, the respondents from 56 and above were $11.67 \%$ of the sample. 


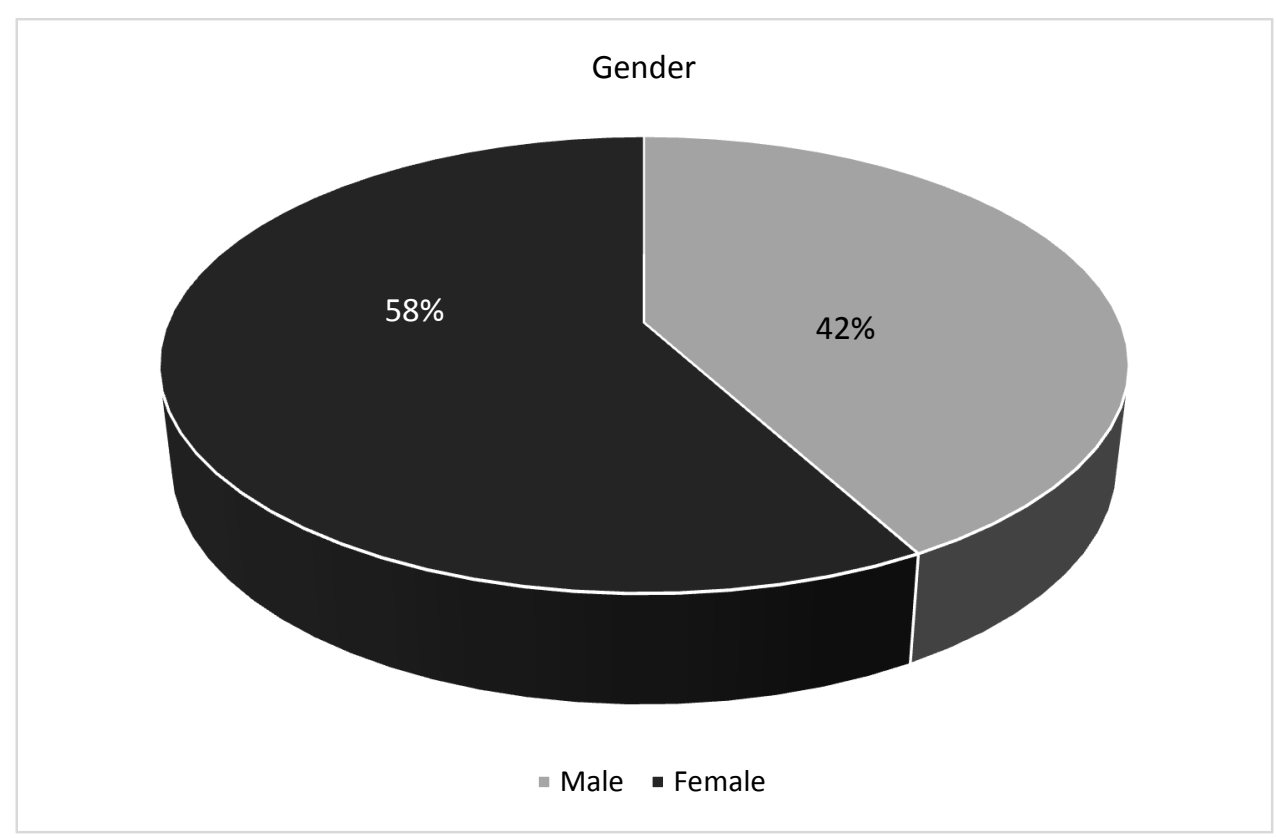

Figure 3. Gender of Respondents

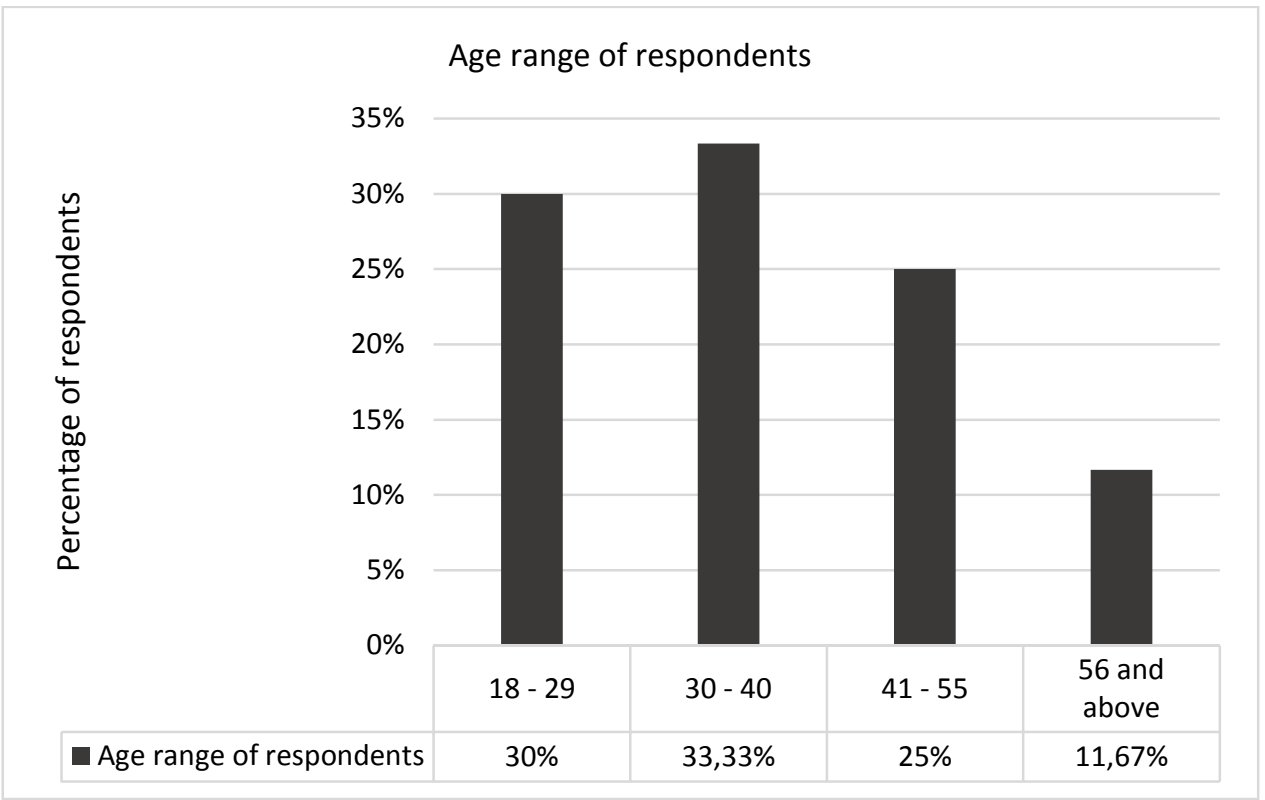

Figure 4. Age of respondents 
Figure 5 illustrates that the preponderance of respondents shop thrice a week (37\%) and it was uncovered that they are in the rural areas of Whittlesea in South Africa. $33.33 \%$ of respondents go shopping more often, $18 \%$ of respondents go shopping twice a week, lastly, $12 \%$ of participants go shopping once a week.

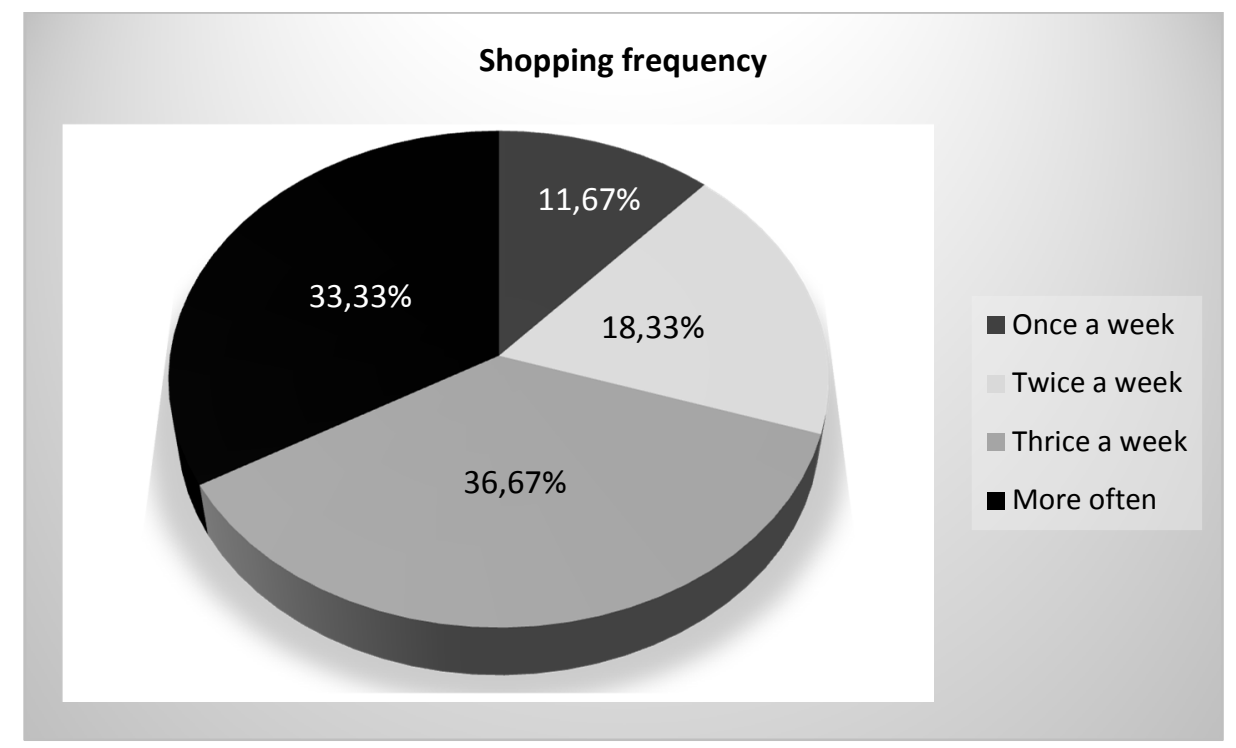

Figure 5. Shopping frequency by respondents

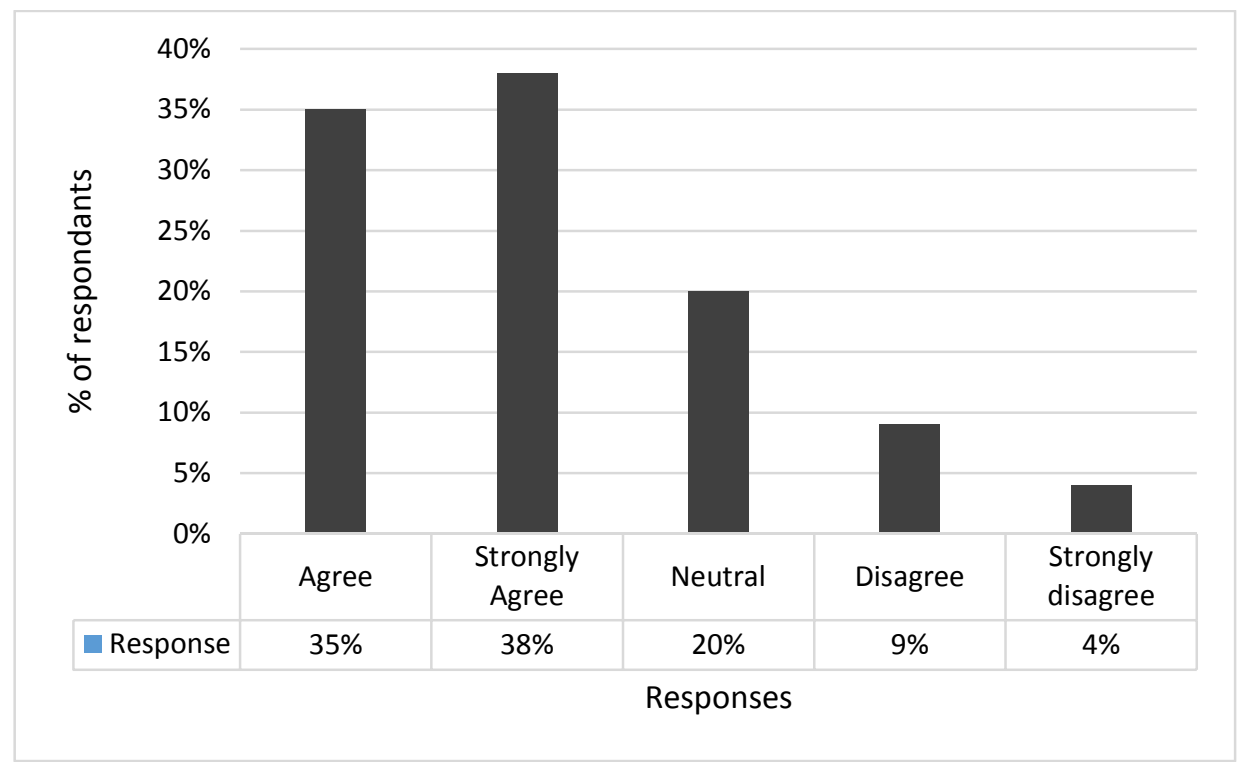

Figure 6. Personnel interested in helping clients 
Figure 6 depicts that $35 \%$ of participants agreed that employees should demonstrate an interest in supporting customers. The workers should demonstrate interest in supporting customers were strongly accepted by $38 \%$ of respondents. Results indicate that $73 \%$ of the respondents expect employees to be prepared to support customers.

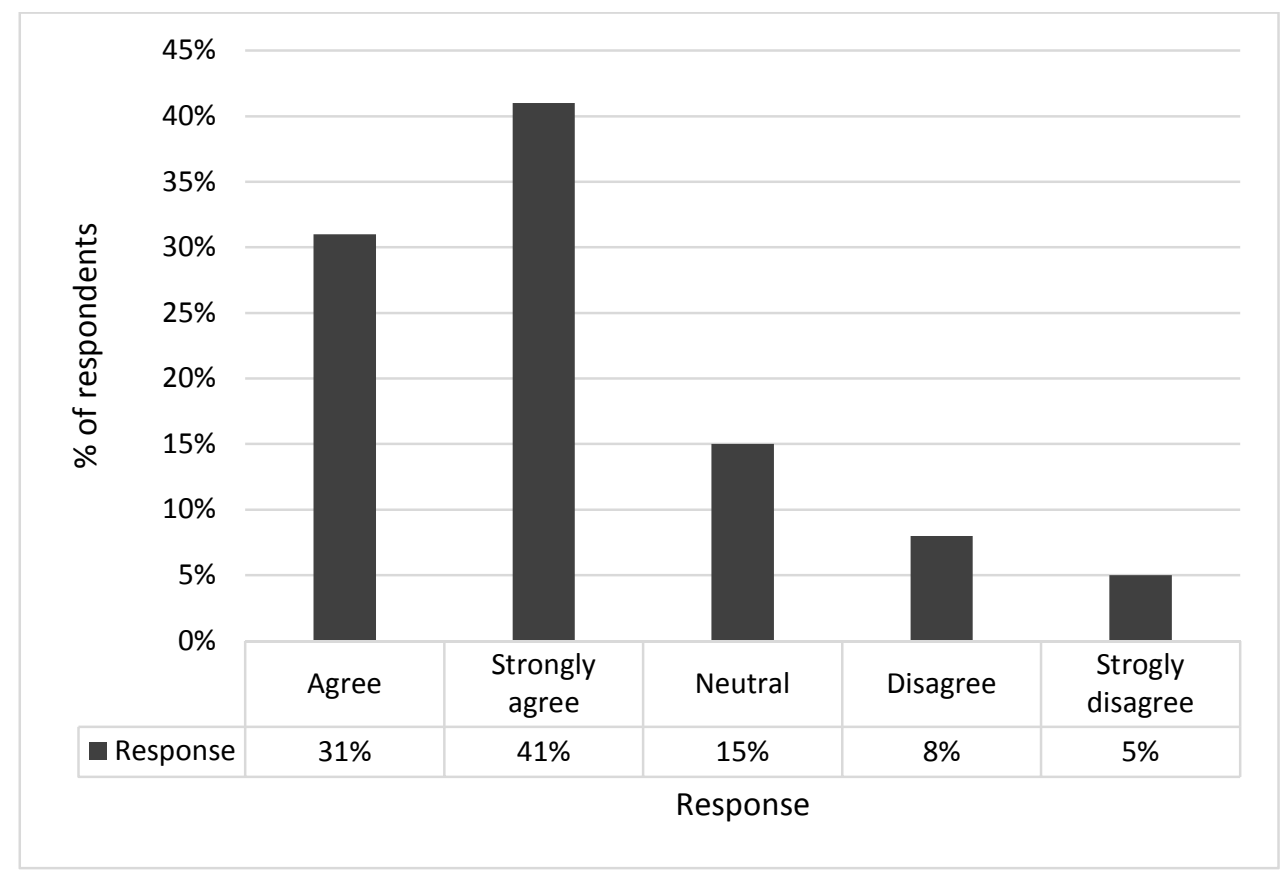

Figure 7. Personnel problem solving

Figure 7 shows that $31 \%$ of participants decided that workers should be able to address customer issues quickly. The vast majority of respondents $(41 \%)$ strongly agreed that employees should be able to address customer issues immediately. Just $8 \%$ of respondents believed that employees should be able to address customer problems. According to the findings, $72 \%$ of participants expect team members to intuitively elucidate consumer plights. As a result, it seems that consumers expect the workers to resolve their problems quickly and decisively.

Figure 8 accurately validates that $13 \%$ of respondents agreed that staff in a selected retail store are polite to customers, although a larger sample proportion (38\%) disagreed. $24 \%$ of those polled were unconcerned about the idea. As a result, the majority of participants are dissatisfied with the courtesy of employees at a selected retail store in Whittlesea. It was recommended that the store should train their employees to be courteous to customers so that they can return to the store and purchase more. 


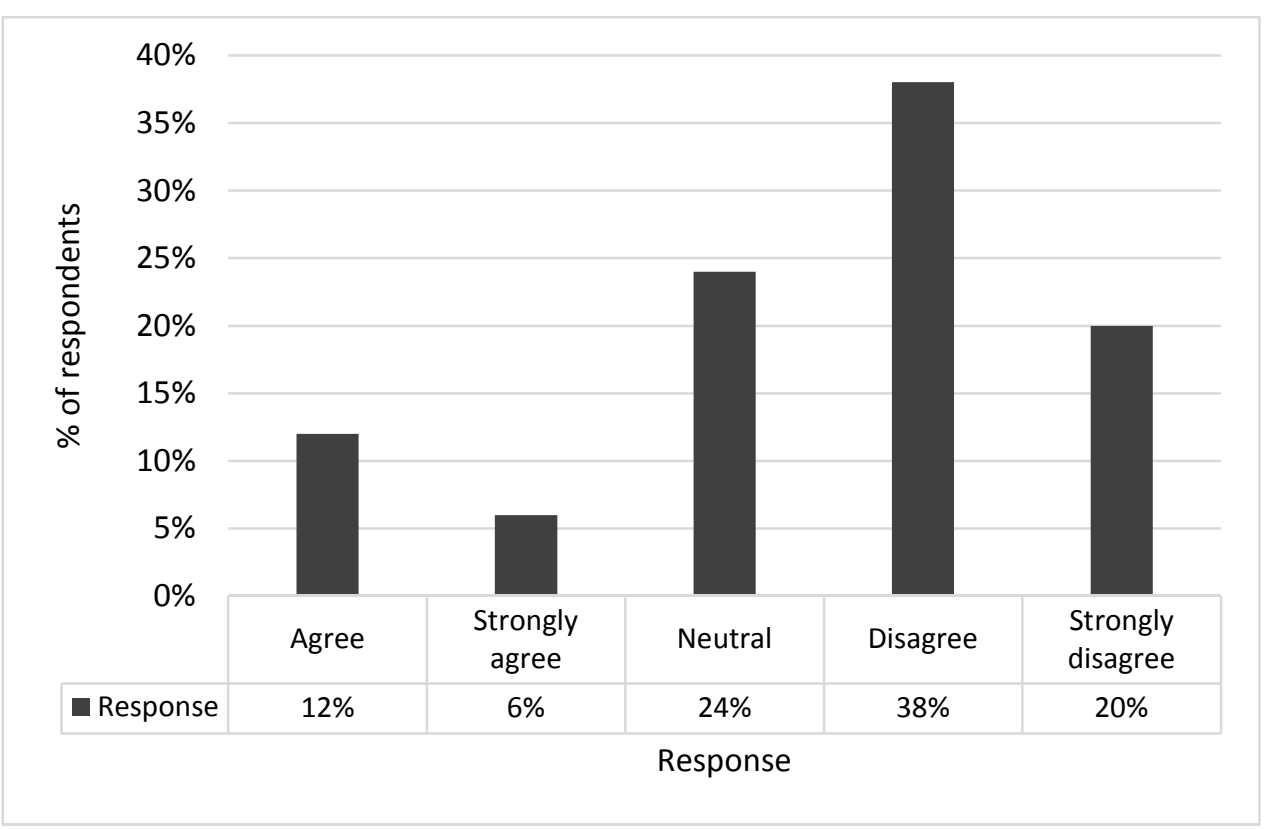

Figure 8. Politeness of staff towards customers

Table 1. Customer Service Expectations

\begin{tabular}{|l|c|c|}
\hline \multicolumn{1}{|c|}{ Customer Service Expectations } & $\begin{array}{c}\text { Number of Responses } \\
\text { (n) }\end{array}$ & $\begin{array}{c}\text { Percentage of respondents } \\
\text { (\%) }\end{array}$ \\
\hline Assist customers whilst shopping & 99 & $73 \%$ \\
\hline Problem Solving & 97 & $72 \%$ \\
\hline The appearance of store personnel & 118 & $87 \%$ \\
\hline Understanding Customers' needs & 115 & $85 \%$ \\
\hline Handle Customer Complaints & 92 & $68 \%$ \\
\hline Staff reliability and trustworthiness & 121 & $90 \%$ \\
\hline Politeness of personnel towards customers & 96 & $71 \%$ \\
\hline $\begin{array}{l}\text { The willingness of staff to assist } \\
\text { customers }\end{array}$ & 92 & $68 \%$ \\
\hline treating customers with respect & 87 & $64 \%$ \\
\hline
\end{tabular}

Source: Own development.

\section{Recommendations based on findings}

It is suggested that retail workers show a desire to help customers. According to the findings, a large percentage of respondents are dissatisfied with the degree of interest displayed by staff members in assisting them. Customer service training is expected to help employees become more sophisticated in their dealings with customers. 
It is strongly recommended that retail employees be able to quickly address customer issues and have a clear understanding of customer expectations and preferences. Customers should be treated with respect by retail employees in order to make them feel comfortable. Workers may receive training in order to improve their communication skills.

\section{CONCLUSION}

This research study has discussed the impact of customer service on purchasing patterns of customers at a selected retailer in Whittlesea in South Africa. It can be concluded that customer service has an impact on the purchasing patterns of consumers. Satisfied customers become loyal. Consequently, good customer service is an extensive strategy to retain customers. Therefore, retailers should strive to provide excellent service to patrons. Retailers should train their employees to be customer-centric and seek to retain customers. Customer service has been shown to increase customers' willingness to shop again, buy more, buy other items, become less price-sensitive, and tell others about their positive experiences, according to Venetis \& Ghauri (2004).

Further research using a survey and monitoring approach to examine and find out more about retail customer service in greater detail are recommended.

\section{REFERENCES}

Adams, R. L. (2016). 10 reasons why good customer service is your most important metric [Access: 28 August 2020]. Access on the internet: https://www.entrepreneur.com/ amphtml/284799.

Cant, C. M., Van Heerden, C. H. (2017). Marketing Management: A South African Perspective. $3^{\text {rd }}$ edition. Cape Town: Juta and Company (Pty) Ltd.

Drury, A. (2020). Customer service [Access: 4 October 2020]. Access on the internet: https://www.investopedia.com/terms/c/customer-service.asp

Jeske, H., Chimusoro, E., Karodia, A. M. (2015). An evaluation of customer service and the impact of efficiency on Namibia's logistical sector: A study involving selected courier companies. "Singaporean Journal of Business, Economics and Management Studies", 3(6).

Joseph, C. (2019). What are the benefits of delivering excellent customer service? [Access: 3 October 2020]. Access on the internet: https://smallbusiness.chron.com/benefitsdelivering-excellent-customer-service-2086.html

Kokemuller, N. (2020). What is customer courtesy? [Access: 4 October 2020]. Access on the internet: https://smallbusiness.chron.com/customer-courtesy-66845.html

Lamb, J., Hair, C., McDaniel, C., Boshoff, C., Terblanche, N., Elliott, R., Klopper, H. B. (2015). Marketing. $5^{\text {th }}$ edition. Cape Town: Oxford.

Marx, N.J.M.M., Erasmus, A. C. (2006). An evaluation of the customer service in supermarkets in Pretoria East, Tshwane Metropolis, South Africa. "Journal of Family Ecology and Consumer Sciences", 34(1).

Megha. (2020). Top 5 benefits of customer satisfaction [Access: 12 September 2020]. Access on the internet: https://www.zonkafeedback.com/blog/benefits-of-customer-satisfaction?hs_ amp=true

Oberlo. (2015). What is customer service? A definition and more - Oberlo wiki [Access: 28 August 2020]. Access on the internet: https://www.oberlo.com/ecommercewiki/customerservice 
Pawlewicz, K. A history of customer service (blog) [Access: 19 August 2020]. Access on the internet: https://blog.olark.com/the-history-customer-service

Quickstone Capital. (2016). 10 critical components of customer service. [Access: 3 October 2020]. Access on the internet: https://www.quickstonecapital.com/merchant-cash-advanceblog/10-critical-components-of-customer-service-0.

Ramroop, T. (2020). Customer service definition and skills for 2020 and beyond [Access: 4 October 2020]. Access on the internet: https://www.zendesk.com/blog/customer-serviceskills/

Setia, P., Venkatesh, V., Joglekar, S. (2013). Leveraging digital technologies: How information quality leads to localized capabilities and customer service performance. "MIS Quarterly", $37(2)$.

Theodoras, D., Laios, L., \& Moschuris, S. (2005). Improving customer service performance within a food supplier-retailers context. International Journal of Retail \& Distribution Management, 33(5), 353-370.

Timesheets. (2017). 7 ways staff can help your marketing [Access: 3 October 2020]. Access on the internet: https://www.timesheets.com/blog/2017/05/7-ways-staff-help-marketing/

Tlapana, T. (2020). Customer Service at Independent Retail Food Chains in Kwazulu-Natal. “Expert Journal of Marketing”, 8(2).

Venetis, K. A., Ghauri, P. N. (2004). Service quality and customer retention: building long-term relationships. "European Journal of marketing”.

DOI: $10.7862 /$ rz.2021.mmr.12

The text was submitted to the editorial office: March 2021.

The text was accepted for publication: June 2021. 